\title{
Köpek ısırığı sonrası Proteus penneri'ye bağlı yara infeksiyonu gelişen olgu
}

\section{Wound infection due to Proteus penneri after dog bite}

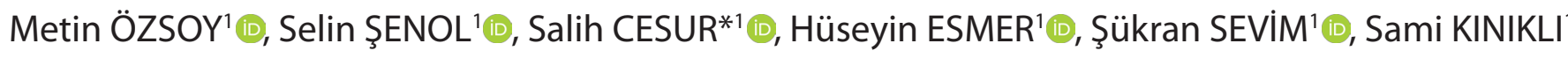 \\ Sultan GÜL² \\ 1SBÜ Ankara Eğitim ve Araştırma Hastanesi, Enfeksiyon Hastalıkları ve Klinik Mikrobiyoloji Kliniği, \\ ${ }^{2}$ SBÜ Ankara Eğitim ve Araştırma Hastanesi,Mikrobiyoloji ve Klinik Mikrobiyoloji Kliniği, Ankara
}

\begin{abstract}
Öz
Proteus penneri (P.penneri) invaziv infeksiyon hastalalıklarına neden olabilen, nadir görülen bir Gram negatif basildir. P.penneri üriner sistem infeksiyonu, yara infeksiyonu, sepsis gibi klinik tablolara neden olabilir. Bu yazıda, köpek ısırığı sonrasında P.penneri'ye bağlı sağ kolunda yara infeksiyonu ve pürülan akıntı gelişen, amoksisilin-klavunat tedavisine yanıt vermeyen 57 yaşında bir kadın olgu sunuldu. Hastaya antibiyogram sonucuna göre piperasilin-tazobaktam tedavisi $3 \times 4.5 \mathrm{gr}$ dozda intravenöz (i.v.) yolla başlandı, tedavi 7 gün süreyle uygulandı. Tedavi sonrası lezyon bölgesindeki akıntı ve yara yeri infeksiyonu tamamen düzeldi.
\end{abstract}

Anahtar kelimeler: Proteus penneri, hayvan ısırığı, yara infeksiyonu

\section{Abstract}

Proteus penneri (P.penneri) is a rare Gram negative bacilli that can cause invasive infectious diseases. P. penneri may cause clinical manifestations such as urinary tract infection, wound infection, sepsis.

In this article, a 57-years-old female patient who developed wound infection and purulent discharge in the shoulder due to $P$. penneri after dog bite was presented and did not respond to amoxicillin-clavunate treatment. According to the antibiogram, piperacillin-tazobactam treatment was started intravenously (i.v.) at a dose of $3 \times 4.5 \mathrm{~g}$. The treatment was administered for 7 days. After treatment, the discharge in the lesion area completely resolved.

Key words: Proteus penneri, animal bite, wound infection

Sorumlu Yazar*: Dr. Salih CESUR, SBÜ Ankara Eğitim ve Araştırma Hastanesi, Enfeksiyon Hastalıkları ve Klinik Mikrobiyoloji Kliniği, Ulucanlar cad. Altındağ/ Ankara

E-mail: : scesur89@yahoo.com

ORCID: 0000-0003-4960-7375

Gönderim: 09.10.2019 Kabul: 23.10.2019

Doi: 10.18663/tjcl.631315 


\section{Giriş}

Hayvan ısırıklarına bağlı olarak yara infeksiyonu gelişimi oldukça sık karşılaşılan bir durumdur, ancak bu konuda yeterli epidemiyolojik veri mevcut değildir. Isırık yarasında infeksiyona neden olan mikroorganizmalar; hayvanın ağız florasında bulunan bakteriler, kişinin cilt florası veya yaralanma ortamındaki mikroorganizmalardan kaynaklanabilir $(1,2)$

Hayvan ısırığına bağlı yara infeksiyonuna neden olan mikroorganizmalar aerob ve anaerob mikroorganizmaların karışımını içerir, bu nedenle hayvan ısırıkları sıklıkla polimikrobiyal infeksiyonlardır (2).

Hayvan ısırığına bağlı yara infeksiyonuna en sık neden olan bakterilerin başlıcaları; stafilokoklar, streptokoklar, anaerob bakteriler, Pasteurella multocida ve Capnocytophaga canimorsus'dur (1,2). Nadiren daha az görülen bazı mikroorganizmalar da hayvan ısırığına bağlı yara infeksiyonuna neden olabilir. Hayvan ısırığına bağlı yara infeksiyonlarında antimikrobiyal tedaviye ilaveten gerekiyorsa cerrahi tedavi ve bazı durumlarda kuduz ve tetanoz profilaksisi de uygulamak gerekebilir (1).

Bu yazıda, köpek ısırığı sonrasında P.penneri'ye bağlı olarak yara infeksiyonu gelişen ve antimikrobiyal tedavi ile tamamen düzelen bir olgu sunarak literatür gözden geçirildi.

\section{Olgu}

Elli yedi yaşında kadın hasta 1 hafta önce sağ üst kol arka yüzünden köpek ısırığı yakınması ile dış merkeze müracat etmiş. Hastaya kuduza yönelik 4 doz aşı ve tetanoza yönelik tek doz aşı profilaksi başlanmış. Hayvan ısırığına yönelik sefaklor $1 \mathrm{gr}$ 2x1 dozda oral yolla başlanmış. Isırık bölgesinde kızarıklık, yeşil renkte kötü kokulu akıntı gelmesi üzerine polikliniğimize başvurmuş. Poliklinikte reçete edilen amoksisilin-klavunat tedavisini 5 gün kullanmasına rağmen akıntısının devam etmesi üzerine hasta kliniğimize yatırıldı.

Anamnezinde altta yatan ek hastalığı yoktu. Fizik muaynede ; ateş 36,7C ; kan basıncı 120/70 mmHg , biyokimyasal testler normaldi. Lökosit sayısı 5210/mm^3; CRP 11,5 mg/L ; sedim $46 \mathrm{~mm} / \mathrm{sa}$ idi. Sağ üst kol arka yüzde ısırık bölgesinde 1 cm' den küçük cilt altı dokuyu geçen $0.5 \mathrm{~cm}$ derinliğinde pürülan akıntı ile karakterize lezyon saptandı (Resim) .

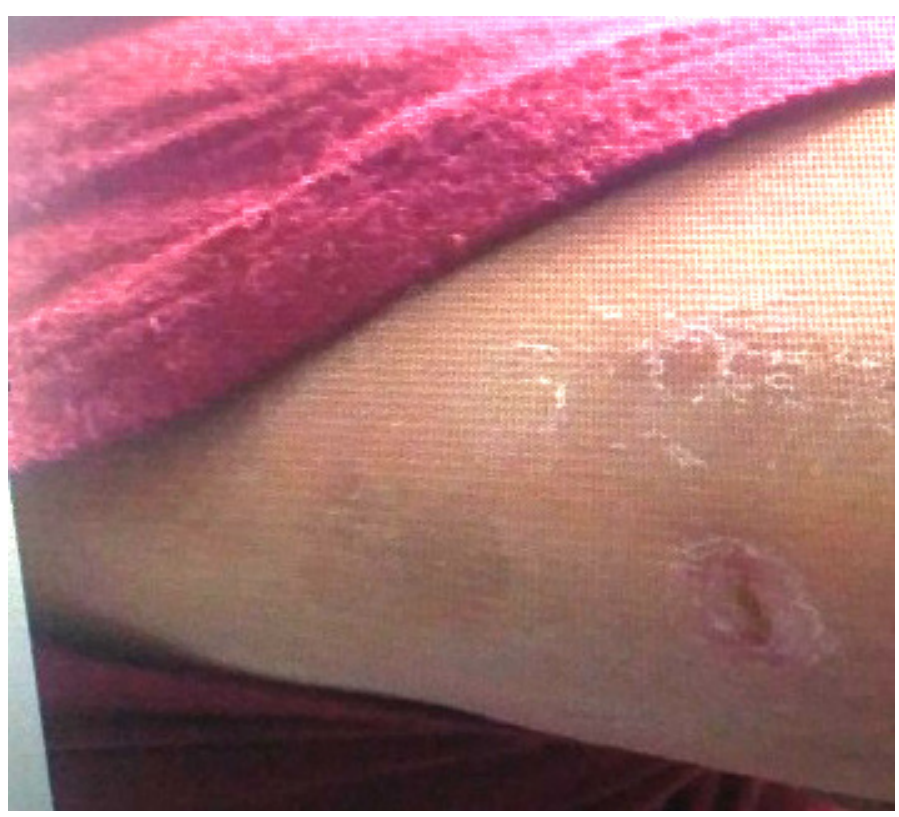

Resim 1. Sağ üst kol arka yüzde ısırık bölgesinde $1 \mathrm{~cm}$ ' den küçük cilt altı dokuyu geçen $0.5 \mathrm{~cm}$ derinliğindeki lezyonun tedavinin 4.günündeki görüntüsü

Lezyon bölgesinden aspirasyonla farklı günlerde alınan akıntı örneğinde P.penneri üredi. Etkenin tanımlanması konvansiyonel yöntemler (TSI, IMVIC testleri) ve VITEK 2 Compact (Biomerieux,Fransa) otomatize identifikasyon ve antimikrobiyal duyarlılık sistemi ve ile yapıldı. İzole edilen suş amikasin, gentamisin, seftazidim, piperasilin-tazobaktam, meropenem ve siprofloksasine duyarlı, ampisilin, sefazolin, sefuroksim, tigesiklin ve kolistine dirençli idi. Antibiyogram sonucuna göre hastaya piperasiln-tazobaktam 3×4.5 gr i.v yolla başlandı.

İzole edilen suş amikasin, gentamisin, seftazidim, piperasilin-tazobaktam, meropenem ve siprofloksasine duyarlı, ampisilin, sefazolin, sefuroksim, tigesiklin ve kolistine dirençli idi. Antibiyogram sonucuna göre hastaya piperasiln-tazobaktam 3x4.5 gr i.v yolla başlandı.

\section{Tartışma}

En sık köpek ısırıkları olmak üzere hayvan ısırıkları ve neden olduğu infeksiyonlar tüm dünyada ve ülkemizde karşılaşılan bir sağlık sorunudur. Kedi ve köpeklerin ağız florasından çeşitli aerob ve anaerob mikroorganizmalar izole edilebilir. Bu hayvanlarla meydana gelen yaralanmalarda gelişen infeksiyonlar çoğunlukla polimikrobiyaldir $(1,2)$. 
Köpek ısırığı infeksiyonlarında en çok Pasteurella multocida'nın etkinliği üzerinde durulsa da; stafilokok türleri, streptokok türleri, korinebakteri ve anaerob bakteriler de izole edilir $(1,2)$. İnfekte köpek ısırığı yaralarında; Pasteurella multocida \%0-25, P. canis \%18, P. stomatis \%6, P. dagmatis \%3, Staphylococcus aureus \%20-40, streptokoklar \%50, anaeroblar \%33 oranında izole edilmiştir . Bazı yayınlarda P. multocida izolasyon oranının daha yüksek olduğu (\%50) bildirilmiştir (1).

P.penneri yoğun bakım ünitesi, klinikler ve poliklinik hastalarının idrar, pü, vücut sıvılarından izole edilebilir. P. penneri, önemli nozokomiyal salgınlara ve infeksiyon hastalıklarına neden olabilir. P.mirabilis ve P.vulgaris'le benzer patojenik belirleyicileri taşır. P. penneri, genellikle idrar yolu, kan, abdominal yara, kasık, boyun ve ayak bileğini enfekte edebilir ve çoğunlukla idrardan (\% 50), yara ve yumuşak doku eksudalarından (\% 25) ve kan kültürlerinden (\% 15) izole edilir. Bazı olgu sunumlarında cilt altı apseden, diabetes mellitus ve epidural apsesi olan bir ürosepsis olgusundan bu bakterinin izole edildiği bildirilmiştir. P.penneri' nin üriner sistem infeksiyonu ve üriner taşı olan hastalar dışında postoperatif dren sıvısı ve pü kültüründen, diyabetik ayak infeksiyonu olan hastalardan da izole edildiği rapor edilmiştir (4-9). Farkındalığın eksik olması ve rutin bakteriyoloji laboratuvarlarının P. penneri izolatlarını tanımlamada yetersiz kalması nedeniyle, bu bakterinin izolasyonu, tanımlanmasında ve bildiriminde sorunlar yaşanmaktadır (4).

P. pennei yara infeksiyonlarından nadiren izole edilir. Köpek ısırığı olgularından en sık infeksiyonuna neden olan bakteriler; Pastorella multicoda, Capnophage canimorsus, streptokoklar, stafilokoklar ve anaerob bakterilerdir $(1,2)$.

P. penneri ilk izolasyondan buğu fenomeni oluşturmayabilir, bu nedenle dikkatli olmak gerekir. P. mirabilis ve P. vulgaris'e benzer şekilde hemolizin, proteolitik enzimler ve çeşitli virülans faktörlerine sahiptir. P. penneri $\mathrm{O}$ antijeni yapısı, biyokimyasal testler, otomatize identifikasyon sistemleri ve moleküler testler ile diğer Proteus spp.'den ayrılabilir. P.penneri, ornitin dekarboksilaz enzimi üretmez,salisin negatif olmasına rağmen, maltozu asidifiye etmesi önemli bir özelliğidir.

Antimikrobiyal ilaç direncinin temel mekanizması kromozomal olarak kodlana beta-laktamaz enziminin aşırı üretilmesidir, bazen plazmid kaynaklı da olabilir (4).

P.penneri' ye bağlı üriner sistem infeksiyonu, diabetik ayak infeksiyonu bildirilmesine rağmen köpek ısırığı veya hayvan ısırığı sonrası yara infeksiyonu gelişen bir olgu ingilizce literatür tarandığı kadarıyla bildirilmemiştir. Olgumuz bu yönüyle ilginçtir. Pandey ve ark. trafik kazası sonrası boğaz bölgesindeki bası bölgesinde genişlemiş spektrumlu beta-laktamaz üreten ve çoklu ilaca dirençli P.penneri'ye bağlı yara infeksiyonu gelişen bir olgu bildirilmiştir (10).

İndol testi negatif Proteus türlerinin detaylı bir mikrobiyolojik tanımlama yapılmazsa yanlışlıkla Proteus mirabilis olarak tanımlandığı ve sıklıkla gözden kaçabildiği bildirilmiştir. İndol negatif türlerin bir kısmı P.penneri'dir. P.penneri çoklu antibiyotik direnci gösterebilir, bu durumda tedavide sorunlar yaşanabilir (4).

P. penneri suşları doğal penisilin G, amoksisilin, sefalosporinlere (örneğin; sefaklor, sefazolin, sefuroksim ve sefdinir), oksasilin ve makrolidlerin çoğuna doğal dirençlidir, ancak aminoglikozidler, aztreonam, karbapenemler, kinolonlar ve trimetoprim-sulfametaksazole duyarlıdır (4). Sunduğumuz olguda hastanın yara yeri aspirasyon kültüründen izole edilen P.penneri suşu amikasin, gentamisin, seftazidim, piperasilintazobaktam, meropenem ve siprofloksasine duyarlı, ampisilin, sefazolin, sefuroksim, tigesiklin ve kolistine dirençli idi. Sunduğumuz hastaya antianerob etkinliğinin ve üreyen etkenin duyarlı olması nedeniyle piperasilin-tazobaktam tedavisi başlandı. Hastada 7 günlük tedavi sonrasında akıntı tamamen düzeldi ve yara yeri kapandı.

Kishore ve ark. P.penneri suşları ile yaptıkları bir çalışmada izolatların çoğunun amoksisilin-klavunatı da içeren çok sayıda antibiyotik grubuna dirençli çoklu ilaca dirençli izolatlar olduğunu bildirmişlerdir (4). Bir başka çalışmada, çoğunlukla ürogenital infeksiyonu olan hastalarda P. penneri'nin penisilinlere ve sefalosporinlere, P. mirabilis'ten daha çok dirençli olduğu rapor edilmiştir (11).Bu nedenle P. penneri'nin tür düzeyinde tanımlanmasının önemli olduğu vurgulanmıştır.

Sunduğumuz olguda hastaya antibiyogram sonucuna göre piperasilin-tazobaktam tedavisi başlandı. Tedavinin 7. gününde akıntı ve yara yeri infeksiyonu tamamen düzeldi.

Sonuç olarak, köpek ısırığı sonrası nadir görülen etkenlerinde yara infeksiyonuna neden olabileceği düşünülmeli ve ısırık bölgesinden kültür için örnek alındıktan sonra ampirik tedavi başlanmalıdır. 


\section{Kaynaklar}

1. Çokca F, Meço O. Hayvan ısırık infeksiyonları. Flora 1996;2:131-136

2. Abrahamian FM, Goldstein EJ. Microbiology of animal bite wound infections.Clin Microbiol Rev. 2011; 24(2):231-46.

3. Drzewiecka D. Significance and Roles of Proteus spp. Bacteria in Natural Environments. Microb Ecol. 2016; 72(4): 741-758.

4. Kishore J. Isolation, identification \& characterization of Proteus penneri - a missed rare pathogen. Indian J Med Res. 2012; 135(3): 341-345.

5. Cantón R, Sánchez-Moreno MP, Morosini Reilly MI. Proteus penneri. Enferm Infecc Microbiol Clin. 2006;24(Suppl 1):8-13.

6. Castro ST, Rodríguez CR, Perazzi BE, Radice M, Paz Sticott M, Muzio $\mathrm{H}$, et al. Comparison of different methods in order to identify Proteus spp. Rev Argent Microbiol. 2006;38:119-24.

7. Krajden S, Fuksa M, Petrea C, Crisp LJ, Penner JL. Expanded clinical spectrum of infections caused by Proteus penneri. J Clin Microbiol. 1987;25:578-9.
8. Engler HD, Troy K, Bottone EJ. Bacteremia and subcutaneous abscess caused by Proteus penneri in a neutropenic host. J Clin Microbiol. 1990;28:1645-6.

9. Latuszynski DK, Schoch P, Qadir MT, Cunha BA. Proteus penneri urosepsis in a patient with diabetes mellitus. Heart Lung. 1998;27:146-8. [PubMed: 9548071]

10. Pandey A, Verma H, Asthana AK, Madan M. Extended spectrum beta lactamase producing Proteus penneri: a rare missed pathogen? Indian J Pathol Microbiol. 2014 ;57(3):489-91.

11. Stock I. Natural antibiotic susceptibility of Proteus spp. with special reference to $P$. mirabilis and P. penneri strains. J Chemother $2003 ; 15: 12-26$. 